\title{
PERBANDINGAN PENGGUNAAN KALORI ATLET PENCAK SILAT KATEGORI SENI TUNGGAL DENGAN SENI REGU BAKU TINGKAT REMAJA PUTERI RD FIGHTING CLUB SUBANG
}

\author{
Tika Sri Anggela, Imas Damayanti
}

Program Studi Ilmu keolahragaan

Departemen Pendidikan Kesehatan dan Rekreasi

Fakultas Pendidikan Olahraga dan Kesehatan

Universitas Pendidikan Indonesia, Jl. Dr. Setiabudhi No. 299 Bandung

Email: azkatika63@gmail.com

\begin{abstract}
Abstrak
Penelitian ini merupakan penelitian perbandingan penggunaan kalori atlet pencak silat kategori seni tunggal dengan seni regu baku. Latar belakang dari penelitian ini didasari karena kurangnya perhatian asupan nutrisi untuk atlet, dan belum adanya penelitian khusus mengenai pengeluaran kalori untuk cabang olahraga pencak silat kategori seni. Tujuan Penelitian ini untuk mengetahui apakah terdapat perbedaan yang signifikan penggunaan kalori atlet pencak silat kategori seni tunggal dengan seni regu baku tingkat remaja puteri. Metode penelitian yang digunakan yaitu deskriptif komparatif. Sampel yang digunakan adalah atlet remaja puteri RD FIGHTING CLUB Subang yang menguasai kategori seni tunggal dengan seni regu baku diambil meggunakan metode purposive sampling. Instrumen yang digunakan adalah Polar FT7. Penghitungan statistik menggunakan SPSS versi 21.0 dan dianalisis menggunakan Independent Sample T Test. Hasil penelitian ini menunjukan nilai $\mathrm{t}=0.869, \mathrm{p}=0.434>0.05$, maka Ho diterima yang berarti tidak terdapat perbedaan yang signifikan penggunaan kalori kategori seni tunggal dengan seni regu baku atlet remaja puteri RD FIGHTING CLUB Subang.
\end{abstract}

Kata kunci: pencak silat, kalori, kategori seni.

\section{PENDAHULUAN}

Olahraga prestasi adalah kegiatan yang dilakukan dan dikelola secara profesional dengan tujuan untuk memperoleh prestasi optimal pada cabang-cabang olahraga. Membina dan mengembangkan olahragawan secara terencana, berjenjang dan berkelanjutan melalui kompetisi, untuk mencapai prestai dapat dicapai dengan dukungan ilmu pengetahuan dan teknologi keolahragaan. Olahraga prestasi dapat dicapai dengan persiapan matang dan memerlukan proses yang baik juga benar.

Hasil tes lapangan yang mengukur kondisi fisik atlet Pelatnas yang diproyeksikan ke SEA Games Malaysia 2017 dan Asian Games Jakarta-Palembang 2018 di Stadion Atletik GOR Rawamangun, Jakarta 5-6 April kurang memuaskan. Dalam tes pertama yang di 
gelar Satuan Pelaksana Program Indonesia Emas (Satlak Prima) masih banyak ditemukan kondisi fisik atlet di bawah standar. Dari tes yang dilakukan selama empat hari, banyak atlet yang cepat mengalami kelelahan. Bahkan, ada beberapa atlet yang pingsan. (Jakarta https://www.Tes Fisik Hari Terakhir, Beberapa Atlet Pingsan _ Lainnya _ Beritasatu.com.htm.)

Fisik menjadi fokus pembenahan Pengurus Cabang Ikatan Pencak Silat Seluruh Indonesia (IPSI) Kabupaten Bandung. Itu hasil evaluasi babak kualifikasi (BK) Pekan oLahraga Daerah (PORDA) XII 2014. “ Berdasarkan evaluasi kami setelah BK lalu, fisik atlet terlihat masih sering ngedrop. Karena itu, kami saat ini fokus di fisik dulu sebelum masuk teknik, kami kejar dulu stamina prima atlet. Karena kondisi fisik ini snagat besar pengaruhnya kepada penguasaan teknik nanti di lapangan". (Sindonews.com https://www.IPSI Bandung genjot fisik pendekar.htm.).

Pelatih atlet Pelatihan Daerah (Pelatda) Pekan Olahraga Nasional (PON) Jawa Barat akhirnya , bicara soal kondisi atlet yang tengah menjalani Pelatda PON di Kota Bekasi. Pelatih yang juga mantan lifter dunia binaan Jawa Barat ini kecewa dengan asupan gizi atlet yang tidak di perhatikan Jabar. Padahal, atlet Pelatda kini tengah diporsir latihan persiapan sebagai persiapan PON 2016 mendatang.POJOK SATU.

Id,

BEKASI.

[Online]http//www.jabar.pojoksatu.id/beka si/2015/08/10/kecewa-asupan-gizi-atlettidak-seimbang.

Pada hakikatnya, pencak silat merupakan paduan pendidikan jasmani, rohani, kesenian dan warisan sosial, serta budaya luhur bangsa Indonesia. Pencak silat adalah salah satu cabang olahraga yang dikategorikan kedalam salah satu aktivitas tinggi yang membutuhkan daya tahan tinggi sehingga akan banyak menghabiskan energi. Ada empat aspek utama dalam pencak silat, yaitu aspek mental spiritual, aspek seni budaya, aspek olahraga dan aspek bela diri. Pencak silat khusus yang dipertandingkan disebut dengan Pencak Silat Olahraga (wiralaga) yang dibagi menjadi 2 yaitu Wira atau Seni TGR dan Laga atau Tanding. TGR (Tunggal,Ganda,Regu) yaitu memperagakan jurus-jurus baku dengan waktu 3 menit, sedangkan tanding atau laga, bertanding dengan teknik-teknik bela serang dalam 3 ronde, 1 ronde 2 menit.

Untuk kategori tunggal dan regu, sistem energi yang dibutuhkan antara anaerob dan aerob adalah 40:60, sehingga kemampuan daya tahan, stamina power menjadi komponen paling penting. Nomor-nomor kategori seni seperti tunggal dan regu, perlu dicari juga tinggi dan berat badan yang ideal, mengingat dalam kategori ini sangat ditunjang pada penampilan dari luar, seperti kebenaran teknik, kebenarana logika gerak dan juga keseragaman gerak. Seperti contoh pada regu, akan menjadi catatan penting bila dicari atlet yang memiliki tinggi dan berat badan yang setara antara satu sama lainnya dalam satu kelompok. Sehingga diharapkan kekompakan dan keserasian gerak.(http//www.perguruansilatsinlamba.b logspot.co.id/2012/07/tes-dan-pengukuranatlet-pencak-silat.html?m=1).

Maka dari itu sistem energi yang dibutuhkan untuk kategori seni tunggal dan seni regu baku yaitu sistem energi aerob, karena energi yang digunakan saat melakukan olahraga ini bersifat ketahanan/endurance. Oleh karena itu atlet- 
atlet yang berpartisipasi dalam ajang-ajang yang bersifat ketahanan ini harus mempunyai kemampuan yang baik dalam memasok oksigen ke dalam tubuh agar proses metabolisme energi secara aerobik dapat berjalan dengan sempurna.

Energi dibutuhkan oleh individu untuk mempertahankan kehidupannya dalam menunjang proses pertumbuhan, serta untuk melakukan aktivitas sehari-hari. Bagi olahragawan/atlet energi adalah suatu prasarat penting untuk penampilan selama latihan dan kompetisi. Menurut Imanudin (2014, hlm. 141) energi diperoleh dari metabolisme atau pengubahan bahan makanan pada tingkat sel-sel otot menjadi campuran energi tinggi dalam bentuk ATP yang disimpan dalam sel otot. ATP terdiri dari satu molekul adenosine dan tiga molekul phosphate.

Setiap kita melakukan aktivitas tentunya membutuhkan energi, begitu pula bila kita melakukan olahraga. Secara garis besar ada dua sistem energi yang disediakan oleh tubuh untuk beraktivitas yaitu aerob dan anaerob. Dalam proses latihan, seorang pelatih penting sekali bahkan harus mengetahui sistem energi apa yang harus digunakan dalam cabang olahraganya. Sehingga dia akan dengan mudah dan tepat dalam memberikan kebutuhan atletnya untuk memenuhi tuntutan dari cabang olahraga itu.

Ditinjau dari segi waktu yang dapat dipertahankan pada penampilan maksimalnya, khususnya pada cabang olahraga dengan intensitas yang homogeny dapat dijelaskan sebagai berikut (Santosa: 2007) :

- 0 - 2 menit sumber energi dominan anaerobik

- 2 - 8 menit sumber energi kombinasi aerob dan anaerob
- $\quad>8$ menit sumber energi dominan aerob

Olahraga dan asupan gizi yang cukup sangat erat hubungannya antara yang satu dengan yang lainnya. Hal ini mempertimbangkan fakta bahwa seorang olahragawan sangat membutuhkan lebih banyak energi (kalori) agardapat melakukan kegiatan olahraganya secara efektif.

Maka dari itu didalam dunia olahraga nutrisi berperan penting untuk menunjang serta dorongan utuk pencapaian prestasi. Mihardja (2004, hlm 1) mengatakan bahwa

"Di dalam tubuh terdapat sejumlah sistem metabolisme energi yang dapat menyediakan energi sesuai kebutuhan metabolisme pada saat istrirahat atau exercise. Peran energi dalam olahraga penting diperhatikan karena kelelahan dapat terjadi akibat tidak cukupnya ketersediaan nutrient energi yang diperlukan dari glikogen atau glukosa darah. Mungkin juga disebabkan tidak berfungsinya sistem energi secara optimal akibat defisiensi nutrient lain seperti vitamin dan mineral. Tubuh dapat menyimpan cadangan energi dalam bentuk lemak tubuh atau jaringan otot. Kelebihan lemak tubuh (obes) atau bekurang berat badan akibat hilangnya jaringan otot dapat mempengaruhi performance atlet."

Kalori dapat diperoleh dari asupan makanan yang mengandung nutrisi, seperti karbohidrat, leak, protein dan alkohol. Nutrisi digunakan untuk maknana sebagai pembentuk energi, dimana setiap jaringan dalam tubuh bekerja dengan bak. Nutrisi juga dapat dikatakan sebagai suatu proses organisme yang menggunakan objek utamanya yaitu mkanan yang sering dikonsumsi dalam kondisi yang normal, dengan menggunakan proses digesti, 
absorsi serta metabolisme yang pada nantinya akan membuang beberapa zat yang memang tidak digunakan oleh tubuh.

"Kalori merupakan satuan standar yang digunakan untuk mengukur nilai energi yang dikandung dalam suatu bahan makanan. Kalori ini merupakan suatu satuan yang setara dengan panas. Jadi kata "kalori" sebenarnya bukan merupakan suatu bentuk zat gizi yang terdapat dalam bahan makanan, melainkan merupakan ungkapan untuk menunjukan potensi panas yang dikandung suatu bahan makanan. Keterangan ini juga dimaksudkan untuk meluruskan pemakaian istilah kalori di Indonesia, menurut Hertog Nursanyoto dkk dalam bukunya yang berjudul Ilmu Gizi , Zat Gizi Utama (1992, hlm. 78-79).”

Sedangkan menurut pakar gizi Ratna Yulia, SP dalam (Kompas, 02 Oktober 2014) "Secara umum kebutuhan kalori untuk laki-laki adalah 2.500 kalori perhari, sementara perempuan membutuhkan sekitar 2.200 kalori perhari dengan patokan gizi seimbang".

Perkembangan pencak silat sebagai olahraga prestasi dibagi menjadi tiga masa, yakni : masa perintisan , masa pemantapan , dan masa perkembangan internasional. Masing-masing masa perkembangan itu memiliki peran penting bagi terwujudnya pencak silat yang mendunia. Tak heran bila pencak silat telah digeluti oleh jutaan orang. Tidak terkecuali yang berada dibelahan Eropa.

"Hal ini menunjukan grafik perkembangan yang sangat pesat. Namun, di balik perkembangan yang sangat pesat tersebut, tercipta tantangan besar, yakni menumbuh kembangkan pencak silat di negeri sendiri. Jadi sebelum kita mengebungebu menduniakan pencak silat, kita harus menanam dulu akar pencak silat, agar tegak kokoh berdiri menurut Murhananto didalam bukunya yang berjudul Menyelami Pencak Silat (1993, hlm. 60-61)."

Kata "seni" mempunyai 2 pengertian, pengertian yang pertama adalah sesuatu yang indah ciptaan manusia. Pengertian yang kedua adalah kiat atau skill, yakni kecakapan, keterampilan atau kemahiran yang tinggi dalam melasanakan sesuatu. Dalam kaitan dengan istilah "Pencak Silat Seni", kata "Seni" berarti kecakapan. Keterampilan dan kemahiran teknis dan taktis yang tinggi dalam melaksanakan Pencak Silat.

Pencak silat seni adalah perwujudan pencak silat yang berupa tatanan gerak etis dan estetis berdasarkan kaidah pencak silat yang mengandung nilai budi pekerti luhur dan bersumber pada khasanah Indonesia. Tujuan pencak silat seni adalah untuk mempertunjukan keindahan gerak pencak silat dengan tujuan menekankan pada aspek seninya. Sedang tujuan pencak silat seni dalam bentuk prestasi atau pertandingan lebih luas lagi, antara lain mengembangkan daya pengendalian diri yang aktif dan dinamis, mengembangkan dan mempererat persatuan dan kesatuan., melestarikan dan memasyarakatkan pencak silat, khususnya pencak silat seni beladiri, serta meningkatkan citra pencak silat sebagai sutau kebanggaan sehingga semakin dikenal dan diminati.

Pada Kongres PERSILAT tahun 1998, Jurus Tunggal Baku ditetapkan menjadi salah satu kategori yang dipertandingkan. Jurus ini disusun oleh team yang anggotanya terdiri dari pakar pencak silat dari empat Negara pendiri PERSILAT, yaitu: IPSI , PERSISI , PESAKA , PERSIB. Seluruh gerak yang terdapat didalam jurus ini diharapkan dapat mewakili gerak pencak silat yang sudah 
disepakati sebagai beladiri asli dari kawasan Asia Tenggara. Disamping itu dengan adanya jurus standar internasional ini dapat pula digunakan sebagai sarana pemersatu seluruh insan pencak silat.

Pakaian untuk seni tunggal baku memakai pakaian pencak silat model standar, warna bebas dan polos (celana dan baju boleh dengan warna yang sama atau berbeda). Memakai ikat kepala dan kain samping warna polos atau bercorak. Pilihan dan kombinasi warna diserahkan kepada peserta. Boleh memakai badge IPSI di dada sebelah kiri.

Senjata golok dengan ukuran antara 30 $\mathrm{cm}$ s.d $40 \mathrm{~cm}$ dan tongkat terbuat dari rotan dengan ukuran panjang antara $150 \mathrm{~cm}$ s.d $180 \mathrm{~cm}$, dengan garis tengah $2,5 \mathrm{~cm}$ s.d 3,5 $\mathrm{cm}$. Waktu penampilan adalah 3 menit.

Penilaian terdiri dari nilai kebenaran (kebenaran gerakan dalam setiap jurus , kebenaran urutan gerakan, kebenaran urutan jurus). Nilai di perhitungkan dari jumlah gerakan Jurus Tunggal Baku (100 gerakan) dikurangi nilai kesalahan. Nilai kemantapan (kemantapan gerak, kemantapan irama gerak,kemantapan penghayatan gerak, kemantapan tenaga dan stamina) pemberian nilai diantara 50 s.d 60 angka yang dinilai secara total/terpadu diantara keempat unsur kemantapan.

Kategori yang menampilkan tiga orang pesilat dari team yang sama memperagakan kemahirannya dalam jurus regu baku secara benar, tepat , mantap penuh penjiwaan dan kompak dengan tangan kosong serta tunduk kepada ketentuan dan peraturan yang berlaku untuk kategori regu.

Pakaian yang digunakan untuk pencak silat seni regu yaitu pakaian pencak silat standard dan berwarna hitam , tidak memakai aksesoris seperti tunggal, hanya memakai sabuk putih. Dengan waktu yang sama seperti tunggal yaitu 3 menit. Jurus seni regu tidak memakai senjata seperti tunggal, gerakannya 100 tangan kosong. Harus digerakan dengan seirama dan kompak . Penilaian terdiri dari nilai kebenaran (kebenaran gerakan dalam setiap jurus , kebenaran urutan gerakan, kebenaran urutan jurus). Nilai di perhitungkan dari jumlah gerakan Jurus Regu Baku (100 gerakan) dikurangi nilai kesalahan. Nilai kemantapan (kemantapan gerak, kemantapan irama gerak,kemantapan penghayatan gerak, kemantapan tenaga dan stamina) pemberian nilai diantara 50 s.d 60 angka yang dinilai secara total/terpadu diantara keempat unsur kemantapan.

Prestasi olahraga yang tinggi perlu terus menerus di pertahankan dan ditingkatkan lagi. Salah satu faktor yang penting untuk mewujudkannya adalah melalui gizi seimbang yaitu energi yang dikeluarkan untuk olahraga harus seimbang atau sama dengan energi yang masuk dari makanan.

Makanan untuk seorang atlet harus mengandung zat tinggi sesuai dengan yang dibutuhkan untuk aktifitas sehari-hari. Makanan harus mengandung zat gizi penghasil energi yang jumlahnya tertentu. Sesuai itu makanan juga harus mampu mengganti zat gzi dalam tubuh yang berkurang akibat digunakan untuk aktifitas olahraga. Gerakan tubuh saat melakukan olahraga dapat terjadi karena otot berkontraksi. Olahraga aerobik dan anaerobik, keduanya memerlukan asupan energi. Namun, penetapan kebutuhan energi secara tepat tidak sederhana dan sangat sulit. Perkembangan ilmu pengetahuan sekarang hanya dapat menghitung kebutuhan energi berdasarkan energi yang dikeluarkan. 
Olahraga merupakan aktivitas fisik yang dilakukan secara terencana untuk berbagi tujuan yang ingin dicapai antara lain untuk memperoleh kesehatan , kebugaran rekreasi, pendidikan dan prestasi. Dalam setiap melakukan aktivitas tidak terlepas dari penggunaan energi, Irianto (2007, hlm. 1) mengungkapkan bahwa energi yang diperlukan untuk kinerja fisik diperoleh dari metabolisme bahan makanan yang dikonsumsi sehari-hari. Berdasarkan alasan tersebut, kiranya tidak berlebihan apabila dikatakan bahwa zat makanan atau zat gizi merupakan salah satu penentu kualitas kinerja fisik dan pertumbuhan seseorang. Metabolisme setiap orang berbeda-beda seperti yang dijelaskan oleh Wiramihardja dkk. (1991, hlm 198) mengungkapkan bahwa "metabolisme setiap orang, bahkan pada orang yang sama namun waktu berbeda, tidaklah sama, selalu berubah tergantung pada keadaan faktor-faktor yang mempengaruhi yaitu : berat dan tinggi badan, umur, kelamin , ativitas fisik , jenis makanan , emosi , kondisi kesehatan serta keadaan lingkungan fisik seperti : suhu udara, kelembaban dan ketinggian tempat. Perubahan metabolisme pada seorang atlet sangat tergantung pada jenis dan lama latihan olahraga/aktivitas fisik yang dijalani“".

Selain itu Irianto (2007, hlm 35) mengungkapkan bahwa , Energi yang dihasilkan dari proses metabolisme juga menghasilkan cadangan energi yang disimpan dalam tubuh berupa ATP, PC, glikogen dan lemak. Selain itu, proses metabolisme juga menghasilkan limbah berupa air, karbondioksida, urea dan asam laktat yang selanjutnya dibuang melalui urin, keringat dan pernafasan. Metabolisme mengandung dua pengertian, yakni anabolisme (sintesa atau proses pembentukan) dan katabolisme. Anabolisme dan katabolisme berlangusng secara serempak. Aktivitas katabolisme meningkat pada saat orang bekerja karena diperlukan sejumlah energi, sedangkan aktivitas anabolisme meningkat pada saat istirahat untuk mengadakan reparasi dan penyimpan cadangan energi.

Dengan pernyataan tersebut, seorang pelatih atau semua praktisi olahraga harus mengetahui jumlah asupan nutrisi atau komposisi zat gizi berdasarkan kebutuhan energi dari setiap atlet. Karena kebutuhan energi setiap atlet nya akan berbeda-beda. Sesuai dengan cabang olahraga masingmasing, intensitas cabang olaharaga tersebut dan tentunya BMR masing-masing atlet.

\section{METODE}

Metode penelitian yang digunakan penelitian kuantitatif, dengan desain penelitian deskriptif komparatif, karena penelitian ini mendeskripsikan dan membandingkan penggunaan kalori antar dua kelompok sampel. Adapun desain penelitiannya digambarkan seperti berikut :

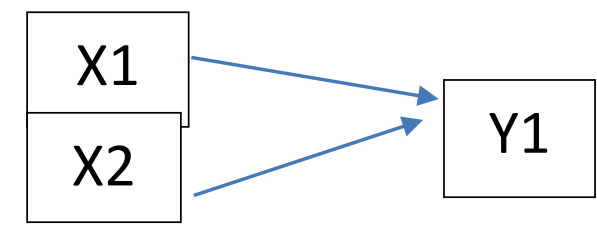

Gambar 3.1

Desain Penelitian

Partisipan yang terlibat dalam penelitian ini adalah atlet remaja dari RD FIGHTING CLUB Subang, usia sampel mulai dari 14-17 tahun. Lokasi penelitian Sekretariat RD FIGHTING CLUB. Remaja puteri yang sudah menguasai jurus-jurus Kategori Seni Tunggal Baku dan Regu Baku. 
Didalam suatu penelitian diperlukan adanya penentuan dan sampel yang memenuhi kriteria dan memiliki karakteristik yang sesuai dengan jenis penelitian yang akan dilaksankan. Menurut Sugiyono (2010, hlm. 215) mengungkapkan bahwa populasi adalah wilayah generalisasi yang terdiri atas obyek/subyek yang mempunyai kualitas dan karakteristik tertentu yang ditetapkan oleh peneliti untuk dipelajari dan kemudian ditarik kesimpulannya. Sedangkan sampel adalah sebagian dari populasi tersebut.

Populasi dari penelitian ini adalah RD FIGHTING CLUB Subang yang beranggotakan 15 orang yang terdiri dari : 10 orang perempuan dan 5 orang laki-laki. Dari keseluruhan anggota perempuan yang sudah menguasai jurus-jurus tunggal dan regu berjumlah 6 orang. Diantara 6 orang ini 3 orang bisa melakukan double kategori yaitu seni tunggal dan seni regu baku. Teknik pengambilan sampling yang peneliti gunakan adalah sampling purposive, karena pada penelitian ini peneliti menentukan sampel dengan pertimbangan tertentu dan harus memiliki kriteria serta karakteristik yang sesuai. Perbandingan penggunaan kalori kategori seni tunggal dengan baku ini harus memiliki syarat yaitu sampel harus memiliki BMI yang sama ,supaya penelitian ini memiliki data yang valid, dengan waktu yang sama dan jumlah jurus yang sama maka sampel harus orang yang sama dengan kata lain sampel yag digunakan harus bisa double kategori, melihat populasi yang ada di RD FIGHTING CLUB Subang, hanya 3 atlet remaja puteri yang bisa double kategori , maka dari itu dalam penelitian ini sampel yang digunakan hanya 3 atlet remaja puteri dari RD FIGHTING CLUB Subang.
Untuk melihat berapa banyak kalori yang digunakan oleh setiap atlet seni tunggal dan regu penulis akan mengukur dengan menggunakan alat ukur untuk memperoleh data. Instrument yang digunakan dalam penelitian ini adalah Polar H7. Fungsi alat tersebut adalah untuk membaca jumlah kalori yang digunakan oleh sampel pada saat menampilkan seni tunggal dan regu.

Untuk teknik analisis data digunakan aplikasi IBM SPSS Statistik versi 21.0. Untuk menganalisis data dalam penelitian ini dilakukan :

Uji normalitas dilakukan untuk mengetahui apakah distribusi data yang didapatkan mengikuti atau mendekati hukum sebaran normal baku GAUSS (Adang Suherman, 2014, hlm. 62). Setelah data didapatkan, maka data langsung di input ke SPSS dan langsung dilakukan uji normalitas data menggunakan one sample kolmogorov smirnov untuk mengetahui apakah pengujian selanjutnya menggunakan statistika parametrik atau nonparametrik:

Pengujian komparasi akan dilakukan menggunakan uji t, yaitu Independent Sample t-Test apabila data berdistribusi normal, sedangkan apabila data tidak berdistribusi normal maka akan digunakan analisis uji Mann-Whitney $\mathbf{U}$, karena penelitian ini menguji perbadingan pada dua kelompok sampel, yaitu sampel dengan kategori seni tunggal baku dan kategori regu.

\section{HASIL DAN PEMBAHASAN}

Dari hasil pengambilan dan pengolahan data bahwa tidak terdapat perbedaaan yang signifikan penggunaan kalori atlet remaja puteri pencak silat dari masing-masing 
kategori seni yaitu seni tunggal baku dengan seni regu baku. Namun dilihat dari rata-rata setiap penggunaan kalori masingmasing kategori jelas terdapat perbedaan penggunaan kalori atlet remaja puteri kategori seni tunggal dengan seni regu baku. Dari hasil rata-rata dapat dijelaskan bahwa penggunaan kalori atlet seni tunggal lebih besar dari pada penggunaan kalori atlet seni regu baku, karena secara teknis dilapangan seni tunggal tidak hanya menggerakan jurus-jurus tangan kosong saja, namun dibagi kedalam 3 kelompok jurus, yaitu jurus tangan kosong, jurus golok dan jurus toya. Maka dari itu membutuhkan konsentrasi yang tinggi untuk memperlihatkan keahlian permainan golok dan toya. Selain itu hal ini terjadi karena sampel yang sedikit, jarang sekali atlet remaja pencak silat yang mampu menguasai double kategori, yaitu seni tunggal dengan seni regu. Kurang terciptanya kondisi seperti saat sedang bertanding, walaupun sudah dijelaskan harus semaksimal mungkin namun mental dan kondisinya nya berbeda dengan pertandingan sebenarnya , dimana tidak ada wasit, lawan bertanding dan penonton. Secara teori pun tunggal akan lebih banyak mengeluarkan kalori karena beban mental dan emosi , Perasaan takut, marah, gembira, kaget dan sebagainya menyebabkan tonus lebih tinggi sehingga keperluan energi pun lebih banyak. Menurut Benedict pengaruh kegiatan mental dapat menaikan basal sebesar $4 \%$. Dalam buku Suhardjo-Clara M.Kusharto "Prinsip-prinsip Ilmu Gizi (hlm 8).

Dari hasil penelitian hari pertama dengan hari ketiga, hari kedua dengan hari keempat terdapat penurunan penggunaan kalori/energi yang digunakan. Di hari pertama untuk tunggal, Euis Karmila 34 kcal dan di hari ketiga 29 kcal, Pipih Viana 25 kcal di hari pertama dan di hari ketiga hanya 22 kcal, Nur Haeni untuk tunggal di hari pertama $21 \mathrm{kcal}$ dan dihari ketiga 20 kcal. Hasil untuk regu di hari kedua Euis Karmila 27 kcal sedangkan di hari keempat 26 kcal, Pipih Viana di hari kedua $21 \mathrm{kcal}$ dan dihari keempat untuk regu 20 kcal, Nur Haeni 19 kcal di hari kedua sedangkan dihari keempat $18 \mathrm{kcal}$. Hal ini disebabkan karena kurangnya asupan energi dari masing-masing sampel, dengan aktivitas sampel yang dimulai dari pagi sampai pengambilan data. Bahkan untuk hari ketiga dan keempat padatnya jadwal kegiatan/aktivitas membuat sampel kelelahan dan kurang maksimal dalam memperagakan setiap gerakan/melakukan simulasi. Di hari keempat pun terjadi sedikit masalah di sensor polar, pada saat awal sebelum gerakan dimulai heart rate sudah terbaca namun pada saat selesai gerakan dan akan dicek kembali sensor tidak terbaca, maka dari itu sampel harus mengulang kembali simulasi, hal ini sampai 3 kali terulang. Maka dari itu pada hari terakhir sampel sangat kelelahan.

Hasil pengkajian para ahli gizi olahraga menunjukan bahwa dengan makanan optimal maka energi dapat tersedia dengan cukup sehingga kemampuan kerja dan waktu pemulihan yang lebih baik. Kelelahan dapat diatasi secara lebih efektif karena zat gizi cadangan dapat digunakan untuk kembali pada keadaan homeostatis. Nutrisi untuk atlet dirancang agar tercapai kecukupan zat gizi yang optimal. Hal ini dijelaskan dalam artikel dr. Laurentia Mihardja, MS dalam artikel nya yang berjudul Sistem Energi Dan Zat Gizi Yang Diperlukan Pada Olahraga Aerobik Dan Anaerobik. 


\section{KESIMPULAN}

Berdasarkan hasil temuan penelitian, uji hipotesis dan pembahasan mengenai Perbandingan Penggunaan Kalori Atlet Pencak Silat Kategori Seni Tunggal dengan Seni Regu Baku Tingkat Remaja Puteri RD FIGHTING CLUB Subang, dengan variabel penelitian yaitu kalori yang dikeluarkan. Maka dapat diperoleh kesimpulan bahwa : (1) Pengeluaran kalori untuk kategori seni tunggal dalam sekali penampilan bisa mencapai $34 \mathrm{kcal}$ dan bisa melebihi dari itu. (2) Pengeluaran kalori untuk kategori seni regu dalam sekali penampilan bisa mencapai $27 \mathrm{kcal}$ dan bisa melebihi dari itu. (3) Tidak terdapat perbedaan yang signifikan pengeluaran kalori kategori seni tunggal dengan seni regu baku dalam olahraga beladiri pencak silat tingkat remaja puteri. Hasil dari uji asumsi ini adalah $\mathrm{t}=0.869, \mathrm{p}=0.434>$ 0.05 , maka Ho diterima, karena nilai signifikansi lebih besar dari 0.05 maka Ho diterima.

\section{DAFTAR PUSTAKA}

Asmira Sutarno. (1980 : 25). Gizi Atlet Pencak Silat. [Online]. Diakses dari http://syawalrasya.blogspot.co.id/2011/01/gizi-atlet-pencak-silat.html

Hertog Nursanyoto, dkk. 1992. Ilmu Gizi. Jakarta : Golden Terayon Press.

Imanudin, I. (2014). Ilmu kepelatihan olahraga. Bandung : Universitas Pendidikan Indonesia

Irianto. (2007). Panduan gizi lengkap keluarga dan olahragawan. Yogyakarta : Andi

Mihardja, L. (2004). Sistem Energi dan Zat Gizi yang Diperlukan pada Olahraga Aerobik dan Anaerobik. Majalah Gizi Medik Indonesia (hlm.9-13). Jakarta: Fakultas Kedokteran, Universitas Indonesia.

Murhananto. (1993). Menyelami Pencak Silat. Jakarta: Pustaka Pembangunan Swadaya Nusantara. PB. IPSI. (2007). "Pedoman Peraturan Pertandingan Pencak Silat”. Jakarta: Hasil Munas IPSI XII 2007.

Sugiyono. (2015). “Metode Penelitian Kuantitatif dan Kualitatif dan $R \& D$ ”. Bandung:Alfabeta.

Suhardjo, Clara M , Kusharto. (1992). “Prinsip-Prinsip Ilmu Gizi”. PoltekesDenpasar

Suherman, Adang \& Rahayu, Indri. (2011). Statistika untuk ilmu keolahragaan. Bandung : Ilmu Keolahragaan, Fakultas Pendidikan Olahraga dan Kesehatan, Universitas Pendidikan Indonesia.

Wiramihardja, dkk. (1991). Manusia dan Olahraga. Bandung: ITB dan FPOK IKIP Bandung. 